\title{
PENGARUH PENGGUNAAN ASAM ASETAT DAN EDIBLE COATING EKSTRAK BAWANG PUTIH TERHADAP KUALITAS FILLET IKAN NILA MERAH (Oreochromis niloticus) SELAMA PENYIMPANAN SUHU DINGIN
}

\author{
EFFECT OF ACETIC ACID AND GARLIC EXTRACT EDIBLE COATING ON RED \\ TILAPIA (Oreochromis niloticus) FILLET QUALITY IN COLD TEMPERATURE STORAGE
}

\author{
Muhammad Luqman Al Hakim(1), Rofandi Hartanto(1), Edhi Nurhartadi(1) \\ ${ }^{(1)}$ Prodi Ilmu dan Teknologi Pangan Universitas Sebelas Maret \\ Jalan Ir. Sutami 36A Surakarta \\ Email: muhammadluqman48@gmail.com
}

\begin{abstract}
This research is aimed to investigate the effect of garlic extract on edible coating and acetic acid addition to red tilapia quality and shelf life during cold storage and knowing the best concentration of garlic extract and acetic acid. This research used Completely Randomized Design (CRD) with two factors, namely, variety of acetic acid and garlic extract concentrations. The research is divided into two parts, garlic extract concentration determination and fish quality analysis with Total Plate Count (TPC), pH, moisture, Thiobarbituric Acid (TBA), Total Volatile Base (TVB), and colour assay (chromameter) during 12 days storage that is tested on day 0, 4, 8, and 12. The result shows that garlic extract minimum inhibitory concentration (MIC) is $20 \%$ and the highest concentration that is still accepted is $30 \%$. Red tilapia fillet soaking into acetic acid solution and garlic extract edible coating addition can inhibit physical, chemical, and microbiological damage until day 8 in storage temperature $4 \pm 1^{\circ} \mathrm{C}$. The best treatment is acetic acid with $1 \%$ concentration and garlic extract with $20 \%$ concentration.
\end{abstract}

Keywords: acetic acid, edible coating, garlic extract, red tilapia, low temperature

\begin{abstract}
ABSTRAK
Tujuan penelitian ini adalah untuk mengetahui pengaruh penambahan ekstrak bawang putih pada edible coating dan penggunaan pengawet asam asetat terhadap kualitas dan umur simpan fillet ikan nila merah selama penyimpanan suhu dingin dan mengetahui konsentrasi ekstrak bawang putih pada edible coating dan konsentrasi asam asetat yang terbaik. Rancangan percobaan yang digunakan adalah Rancangan Acak Lengkap (RAL) dengan dua faktor yaitu variasi konsentrasi asam asetat dan ekstrak bawang putih. Penelitian ini terbagi menjadi dua bagian yaitu penentuan konsentrasi ekstrak bawang putih yang ditambahkan pada edible coating dan pengujian kesegaran daging ikan dengan uji TPC (Total Plate Count), pH, kadar air, TBA (Thiobarbituric Acid), TVB (Total Volatile Base), dan warna (chromameter) selama 12 hari yang diuji pada hari ke-0, 4, 8, dan 12 . Hasil penelitian menunjukkan bahwa konsentrasi hambat minimum (KHM) ekstrak bawang putih adalah 20\% dan konsentrasi tertinggi yang masih diterima oleh panelis adalah 30\%. Perendaman fillet ikan nila merah dalam asam asetat dan pelapisan edible coating ekstrak bawang putih dapat menghambat kerusakan fisik, kimia, dan mikrobiologis sampai hari ke-8 pada suhu penyimpanan $4 \pm 1^{\circ} \mathrm{C}$. Perlakuan terbaik adalah asam asetat dengan konsentrasi $1 \%$ dan ekstrak bawang putih $20 \%$.
\end{abstract}

Kata Kunci : asam asetat, edible coating, ekstrak bawang putih, nila merah, suhu rendah

\section{PENDAHULUAN}

Ikan nila merah (Oreochromis niloticus) merupakan salah satu jenis ikan air tawar potensial karena mudah dibudidayakan, rasanya yang enak digemari masyarakat luas di Indonesia, dan produksinya melimpah. Budidaya ikan nila khususnya di daerah ekskaresidenan Surakarta yang paling terkenal adalah daerah Minapolitan, Klaten. Data yang dihimpun Solopos (2013) di Bidang Perikanan Dinas Pertanian (Dispertan) Klaten, pada 2010 produksi ikan nila di Minapolitan mencapai 2.752 ton. Jumlah produksi ikan tersebut meningkat hingga dua kali lipat pada 2011, yakni mencapai 5.763 ton. Pada 2012 produksi ikan nila di Minapolitan mencapai 9.131 ton. Produksi ikan nila yang menjadi ciri khas kawasan Minapolitan, Klaten, terus meningkat dari 
tahun ke tahun. Hingga Juni 2013, produksi ikan di kawasan Minapolitan telah menembus 5.103 ton. Umumnya ikan nila merah disajikan dan dijual dalam bentuk ikan secara utuh ataupun potongan filet (daging tanpa tulang). Nila merah berpotensi sebagai bahan baku fillet, karena memiliki daging tebal dengan sedikit duri dan warna daging putih bersih. Nila merah pertumbuhannya lebih cepat, mudah dikembangbiakkan, efisien pakan, resisten terhadap hama, dan mudah beradaptasi dengan lingkungan (Djarijah, 1995), sehingga fillet ikan nila merah sangat potensial untuk dikembangkan terutama untuk pasar ritel di Indonesia.

Daging ikan pada umumnya cepat rusak. Kerusakan dapat terjadi secara fisik, kimia, maupun secara mikrobiologis. Konsep pengawetan daging ikan yang paling mudah adalah dengan penggunaan suhu rendah selama penyimpanan. Konsep ini banyak diaplikasikan di supermarket yang menjual produk daging dingin yang dikemas dengan styrofoam dan plastik wrap. Daging ikan hanya memiliki umur simpan kurang dari 1 hari pada suhu $38^{\circ} \mathrm{C}, 1$ hari pada suhu $22^{\circ} \mathrm{C}$, dan 2-7 hari pada suhu $0^{\circ} \mathrm{C}$ (suhu dingin). Pada suhu dingin $\left(0-10{ }^{\circ} \mathrm{C}\right)$ pun mikroba psikrofilik masih dapat tumbuh sehingga dapat menjadi sumber kontaminasi.

Sementara menurut Buckle et al. (2010) pada suhu beku $0{ }^{\circ} \mathrm{C}$ sampai $-20^{\circ} \mathrm{C}$ ikan dapat bertahan lebih lama tetapi tidak mampu mencegah dari denaturasi protein dan ketengikan lemak. Pemakaian suhu rendah saja belum cukup untuk mempertahankan mutu fillet ikan, baik kerusakan secara kimiawi maupun mikrobiologi.

Penggunaan suhu rendah dapat digabungkan dengan metode pengemasan. Pengemasan merupakan salah satu cara untuk menghambat kerusakan denaturasi protein dan ketengikan lemak. Pengemasan yang mudah, aman, murah, dan dapat dikonsumsi adalah edible coating. Edible coating merupakan cara pengemasan yang bersifat biodegradable yang mampu mencegah daging ikan (fillet) kontak dengan udara bebas yang mengakibatkan kerusakan lemak secara oksidatif. Penggunaan edible coating dapat digabungkan dengan penambahan antimikroba seperti ekstrak bawang putih. Pada beberapa penelitian, antimikroba dari ekstrak bawang putih dapat menghambat pertumbuhan mikroba yang dapat menurunkan kualitas daging selama penyimpanan. Selain penggunaan antimikroba dalam edible coating, pada penelitian ini diaplikasikan perendaman fillet dalam pengawet asam asetat yang berfungsi untuk menurunkan $\mathrm{pH}$, sehingga mikroba psikrofilik (umumnya tidak tahan pada $\mathrm{pH}$ yang asam) pertumbuhannya akan terhambat. Asam asetat digunakan karena merupakan antimikroba, aman bagi tubuh, dan tidak memiliki batasan maksimum. Penelitian ini menggunakan hurdle concept, yaitu penggabungan beberapa faktor untuk pengawetan bahan pangan. Antara lain penurunan $\mathrm{pH}$ (pengasaman), senyawa antimikroba, kemasan edible coating, dan penyimpanan suhu dingin.

Penelitian ini bertujuan untuk mengetahui pengaruh dan konsentrasi penambahan ekstrak bawang putih pada edible coating dan penggunaan pengawet asam asetat terhadap kualitas dan umur simpan fillet ikan nila merah selama penyimpanan suhu dingin.

\section{METODE PENELITIAN}

\section{Bahan}

Ikan nila merah (didapatkan Polanharjo, Klaten), Asam asetat (teknis), tepung tapioka, - gliserol -,Kemudian bawang putih (Allium sativum), bakteri Pseudomonas fluorescens FNCC 0071, media Nutrient Agar (NA), dan Nutrient Broth (NB). Bahan Analisis TVB (Total Volatile Base), TBA (Thiobarbituric Acid), TPC (Total Plate Count). Akuades. Buffer $\mathrm{pH} 4$ dan 7.

\section{Alat}

Pisau, juicer Miyako JE-507, gelas beker Pyrex 100 ml, 250 ml, 500 ml, dan 1000 $\mathrm{ml}$, pengaduk, pemanas, magnetic stirrer, cawan petri, jarum inokulasi, kertas uji organoleptik, alat tulis, inkubator, wadah fillet (plastik wrap dan styrofoam), timbangan 
analitik kepekaan 0,1 mg, blender, blender jari kapasitas $100 \mathrm{ml}$, stopwatch, erlenmeyer $250 \mathrm{ml}$, corong, kertas saring, gelas ukur 100 $\mathrm{ml}$, pipet Pyrex skala $1 \mathrm{ml}, 5 \mathrm{ml}, 10 \mathrm{ml}$, cawan Conway diameter $6 \mathrm{~cm}$ dan tutupnya, inkubator, buret $2 \mathrm{ml}$ skala $0,05 \mathrm{ml}$, spektrofotometer Shimadzu, blender, labu destilasi, pipet volume, penangas air, tabung reaksi, pipet mikro, blender, petridish, vortex, botol media, colony counter, pembakar bunsen, inkubator, autoclave, dan refrigerator, $\mathrm{pH}$ meter, Konika Minolta CR400/41 Chromameter, oven, cawan porselen, penjepit, dan desikator.

\section{Tahapan Penelitian}

\section{Pembuatan Fillet Ikan Nila Merah}

Ikan nila merah yang dipilih adalah ikan dengan berat $500-600$ gram per ikan. Ikan nila merah dihilangkan kulit sisiknya dan daging dipotong secara vertikal tegak lurus dengan tulang belakang ikan. Kemudian dicuci dengan air mengalir. Daging ikan (fillet) nila merah yang sudah dibersihkan dengan air mengalir, lalu dipotong dengan berat $25-30$ gram per potong.

\section{Pembuatan Ekstrak Bawang Putih}

Ekstrak bawang putih didapatkan dari proses pengupasan kulit, pembersihan dengan alkohol $70 \%$, penyinaran UV selama 30 menit, kemudian penghancuran dan penyaringan dengan juicer.

\section{Pembuatan Larutan Edible Coating Ekstrak Bawang Putih}

Larutan edible coating dibuat dari tepung tapioka $(5 \% \mathrm{v} / \mathrm{v})$, gliserol $(2 \% \mathrm{v} / \mathrm{v})$, akuades, dengan pemanasan pada suhu $70^{\circ} \mathrm{C}$ selama 30 menit kemudian ditambahkan ekstrak bawang putih dengan berbagai konsentrasi.

\section{Penentuan Konsentrasi Ekstrak Bawang Putih Pada Edible Coating}

Penentuan konsentrasi dibagi dua yaitu konsentrasi terendah dan konsentrasi tertinggi. Konsentrasi terendah atau Konsentrasi Hambat Minimum (KHM) ditentukan dengan pengujian aktivitas antimikroba dengan metode Difusi Agar Kertas Cakram. Konsentrasi ekstrak bawang putih (v/v) yang akan diuji adalah 0\%, 15\%, $20 \%$, dan $25 \%$. Pengujian menggunakan bakteri Pseudomonas fluorescens FNCC 0071. Konsentrasi tertinggi/maksimum ditentukan dengan uji organoleptik metode kesukaan dan perbandingan jamak setelah KHM didapatkan. Uji ini mengamati penampakan fisik meliputi aroma, rasa, dan warna.

\section{Aplikasi Asam Asetat dan Edible Coating Ekstrak Bawang Putih pada Fillet Ikan Nila Merah}

Fillet ikan nila merah direndam ke dalam larutan asam asetat selama 15 menit, setelah itu dicelupkan ke dalam larutan edible coating dua kali lalu dikeringkan-anginkan dengan pengering. Kemudian sampel diletakkan ke dalam Styrofoam dan ditutup dengan plastik wrap. Kemudian sampel disimpan pada refrigerator dengan suhu $4^{\circ} \mathrm{C}$ \pm 1 dan dianalisis pada waktu yang telah ditentukan.

\section{Pengujian Kualitas dan Kerusakan Fillet Ikan Nila Merah}

Sampel fillet ikan nila kontrol dan sampel telah diberi perlakuan perendaman variasi konsentrasi asam asetat dan variasi konsentrasi ekstrak bawang putih pada edible coating, disimpan pada suhu dingin $\left(4^{\circ} \mathrm{C} \pm 1\right)$ kemudian dianalisis pada hari ke- $0,4,8$, dan 12. Metode analisis antara lain uji TPC, $\mathrm{pH}$, kadar air, TBA, TVB, dan warna.

\section{Rancangan Percobaan}

Rancangan yang digunakan adalah Rancangan Acak Lengkap (RAL) dengan dua faktor, yaitu variasi konsentrasi asam asetat (A) dan variasi konsentrasi ekstrak bawang putih (B) pada edible coating dengan dua kali ulangan sampel dan ulangan analisis. Sedangkan sampel kontrol tidak diberi ekstrak bawang putih pada edible coating maupun perendaman asam asetat. Data yang diperoleh dianalisis menggunakan One Way Analysis of Variance (ANOVA) dengan 
$\alpha=0,05$. Jika terdapat perbedaan $(\alpha<0,05)$ maka dilanjutkan dengan uji Duncan Multiple Range Test (DMRT) untuk mengetahui ada tidaknya perbedaan pada masing-masing sampel pada tingkat signifikasi $\alpha=0,05$.

\section{HASIL DAN PEMBAHASAN}

\section{Penentuan Konsentrasi Ekstrak Bawang Putih pada Edible Coating}

Pengujian aktivitas antimikroba dilakukan dengan metode Difusi Agar Kertas Cakram untuk mengetahui ada tidaknya daya penghambatan larutan edible coating ekstrak bawang putih terhadap mikroba Pseudomonas flourescens FNCC 0071 yang ditandai dengan adanya zona bening di sekitar cakram. Pseudomonas adalah bakteri psikrofilik yang menyebabkan kebusukan bahan pangan yang disimpan pada suhu rendah.

Hasil analisis aktivitas antimikroba menunjukkan bahwa sampel 0\% (kontrol) tidak memberikan daya hambat terhadap mikroba (seperti yang terlihat pada Tabel 1). Pada sampel $15 \%$ menunjukkan zona penghambatan sebesar $0,81 \pm 0,24 \mathrm{~mm}$, namun dinilai tidak beda nyata dengan sampel kontrol. Pada sampel 20\% dan 25\% secara berturut-turut memberikan zona penghambatan sebesar $4,38 \pm 0,48 \mathrm{~mm}$ dan $5 \pm 0,91 \mathrm{~mm}$ yang pada keduanya tidak beda nyata. Namun pada sampel $20 \%$ berbeda nyata terhadap sampel kontrol sehingga konsentrasi $20 \%$ dipilih sebagai konsentrasi terendah. Menurut Davis dan Stout (1971) dalam Dewi (2010) kategori daya hambat bakteri kurang dari $5 \mathrm{~mm}$ adalah lemah, sehingga konsentrasi 20\% termasuk kategori lemah. Senyawa pada ekstrak bawang putih yang dapat menghambat pertumbuhan mikroba adalah senyawa tiosulfinat seperti alisin. Alisin menghambat sintesis RNA dan sebagian sintesis DNA mikroba. Selain itu, menurut Sutomo (1987) dalam Rusdy (2009) komponen bioaktif yang terdapat dalam bawang putih adalah aliin, scordinin, metilalin trisulfida, saltivine, dan minyak atsiri.

Tabel 1 Hasil Analisis Zona Bening Larutan Edible Coating Ekstrak Bawang Putih terhadap Mikroba Pseudomonas flourescens FNCC 0071

\begin{tabular}{lc}
\hline \multicolumn{1}{c}{ Konsentrasi (v/v) } & Zona Bening $(\mathrm{mm})$ \\
\hline $0 \%($ Kontrol) & $0 \pm 0^{\mathrm{a}}$ \\
$15 \%$ & $0,81 \pm 0,24^{\mathrm{a}}$ \\
$20 \%$ & $4,38 \pm 0,48^{\mathrm{b}}$ \\
$25 \%$ & $5,00 \pm 0,91^{\mathrm{b}}$ \\
\hline
\end{tabular}

Keterangan : Nilai adalah rata-rata \pm standar deviasi $(n=4)$. Notasi huruf yang sama pada kolom yang sama menunjukkan tidak beda nyata pada taraf signifikansi $(\alpha=0,05)$

\section{Uji Kesukaan}

Ringkasan hasil uji kesukaan dapat dilihat pada Tabel 2. Pada parameter warna konsentrasi ekstrak bawang putih $0 \%$ (kontrol) pada edible film mendapat skor 5,92 yang berarti disukai. Kemudian pada konsentrasi $20 \%$ terlihat berbeda nyata dengan sampel kontrol dengan skor 4,76 yang berarti masih dalam rentang agak suka. Sedangkan pada sampel $25 \%$ didapatkan hasil yang tidak berbeda nyata dengan sampel $20 \%$ dengan skor 4,12 yang berarti netral. Pada sampel $30 \%$ sudah berbeda nyata dengan $20 \%$ dengan skor 3,68 atau masih dalam rentang netral atau mendekati skor kurang disukai $(3,5)$.

Pada parameter aroma, semua perlakuan yaitu $0 \%$ (kontrol), 20\%, 25\%, dan $30 \%$ tidak beda nyata oleh panelis dengan skor berturut-turut 5,12; 5,08; 5,08; dan 4,84 yang berarti semua perlakuan berada pada rentang agak disukai panelis. Pada parameter overall (keseluruhan), perlakuan kontrol mendapat skor tertinggi secara signifikan daripada perlakuan lain, yaitu 5,2 yang berarti agak disukai panelis. Sedangkan antar perlakuan yang diberi tambahan ekstrak bawang putih $20 \%$, 25\%, dan $30 \%$ tidak berbeda nyata, masing-masing mendapat skor 4,$16 ; 3,76$; dan 3,8 yang berarti masih dalam rentang netral. 
Tabel 2 Hasil Uji Kesukaan Edible Film Ekstrak Bawang Putih

\begin{tabular}{cccc}
\hline $\begin{array}{c}\text { Konsentrasi Ekstrak } \\
\text { Bawang Putih (v/v) }\end{array}$ & Warna & Aroma & Overall \\
\hline $0 \%$ & $5,92 \pm 1,15^{\mathrm{a}}$ & $5,12 \pm 1,30^{\mathrm{a}}$ & $5,20 \pm 1,04^{\mathrm{a}}$ \\
$20 \%$ & $4,76 \pm 1,20^{\mathrm{b}}$ & $5,08 \pm 1,12^{\mathrm{a}}$ & $4,16 \pm 1,18^{\mathrm{b}}$ \\
$25 \%$ & $4,12 \pm 1,36^{\mathrm{bc}}$ & $5,08 \pm 1,26^{\mathrm{a}}$ & $3,76 \pm 1,01^{\mathrm{b}}$ \\
$30 \%$ & $3,68 \pm 1,46^{\mathrm{c}}$ & $4,84 \pm 1,34^{\mathrm{a}}$ & $3,80 \pm 1,32^{\mathrm{b}}$ \\
\hline
\end{tabular}

Keterangan: Nilai menunjukkan rata-rata \pm standar deviasi $(\mathrm{n}=25)$. Notasi huruf kecil yang sama pada kolom yang sama menunjukkan tidak beda nyata pada taraf signifikansi $(\alpha=0,05)$. Tingkat uji kesukaan ( $1=$ Sangat Tidak Suka, $2=$ Tidak Suka, $3=$ Kurang Suka, 4=Netral, 5=Agak Suka, 6=Suka, 7=Sangat Suka).

\section{Uji Perbandingan Jamak}

Ringkasan hasil uji kesukaan perbandingan jamak dapat dilihat pada Tabel 3. Pada parameter warna, perlakuan $20 \%$, $25 \%$, dan $30 \%$ tidak saling berbeda nyata. Perlakuan $20 \%$ dan $25 \%$ mendapat skor 1,52 dan 1,68 yang berarti masih dinilai sama dengan sampel 0\% (kontrol). Pada perlakuan $30 \%$ mendapat skor 1,4 yang berarti sudah cenderung lebih buruk daripada sampel kontrol, namun dinilai tidak beda nyata dengan sampel $20 \%$ dan $25 \%$. Ini menunjukkan bahwa pada tingkat penambahan ekstrak bawang putih dari $20 \%$ sampai $30 \%$ dinilai sama oleh panelis terhadap parameter warna. Pada parameter aroma, sampel $20 \%$ dan $25 \%$ mendapat skor masing-masing 2,40 dan 2,52 yang berarti masih dinilai sama dengan sampel $0 \%$ (kontrol). Sedangkan sampel 30\% dengan skor 2,60 dinilai sedikit lebih baik daripada sampel $0 \%$ (kontrol). Namun, ketiganya dinilai tidak berbeda nyata. Ini menunjukkan bahwa pada tingkat penambahan ekstrak bawang putih dari $20 \%$ sampai $30 \%$ dinilai sama oleh panelis terhadap parameter aroma. Pada parameter overall, sampel 20\%, 25\%, dan 30\% mendapat skor masing-masing 1,68; 1,60; dan 1,52 yang berarti masih dinilai sama dengan sampel 0\% (kontrol). Namun, ketiganya dinilai tidak berbeda nyata. Ini menunjukkan bahwa pada tingkat penambahan ekstrak bawang putih dari $20 \%$ sampai $30 \%$ dinilai sama oleh panelis terhadap parameter overall.

\section{Penentuan Konsentrasi Terendah dan Tertinggi}

Ringkasan konsentrasi yang terendah dan tertinggi dapat dilihat pada Tabel 4 . Konsentrasi terendah adalah ekstrak bawang putih sebesar 20\%. Konsentrasi ini dipilih karena memberikan beda nyata ukuran zona bening dibandingkan dengan sampel kontrol. Sedangkan konsentrasi tertinggi adalah ekstrak bawang putih sebesar $30 \%$. Konsentrasi ini dipilih karena memberikan beda nyata parameter warna pada uji kesukaan dibandingkan sampel kontrol $(0 \%)$ dan konsentrasi terendah (20\%) tetapi masih dalam rentang diterima oleh panelis (skor netral).

Tabel 3 Hasil Uji Perbandingan Jamak Edible Film Ekstrak Bawang Putih

\begin{tabular}{cccc}
\hline $\begin{array}{c}\text { Konsentrasi Ekstrak } \\
\text { Bawang Putih (v/v) }\end{array}$ & Warna & Aroma & Overall \\
\hline $20 \%$ & $1,52 \pm 0,87^{\mathrm{a}}$ & $2,40 \pm 0,87^{\mathrm{a}}$ & $1,68 \pm 0,80^{\mathrm{a}}$ \\
$25 \%$ & $1,68 \pm 0,95^{\mathrm{a}}$ & $2,52 \pm 0,71^{\mathrm{a}}$ & $1,60 \pm 0,87^{\mathrm{a}}$ \\
$30 \%$ & $1,40 \pm 0,82^{\mathrm{a}}$ & $2,60 \pm 0,65^{\mathrm{a}}$ & $1,52 \pm 0,87^{\mathrm{a}}$ \\
\hline
\end{tabular}

Keterangan: Nilai menunjukkan rata-rata \pm standar deviasi $(n=25)$. Notasi huruf kecil yang sama pada kolom yang sama menunjukkan tidak beda nyata pada taraf signifikansi $(\alpha=0,05)$. Tingkat uji perbandingan jamak ( $1=$ Lebih buruk daripada kontrol, 2=Sama dengan kontrol, $3=$ Lebih baik daripada control) 
Tabel 4 Penentuan Konsentrasi Terendah dan Tertinggi

\begin{tabular}{lc}
\hline Jenis Konsentrasi & Konsentrasi terpilih \\
\hline Konsentrasi terendah & $20 \%(\mathrm{v} / \mathrm{v})$ \\
Konsentrasi tertinggi & $30 \%(\mathrm{v} / \mathrm{v})$ \\
\hline
\end{tabular}

\section{Total Plate Count (TPC)}

Pada hari ke-0, jumlah koloni masih sekitar 2,41-3,36 log CFU/g (dapat dilihat pada Gambar 1). Pada hari ke-4, mikroba pada semua sampel tumbuh dengan cepat, sekitar 4,27-5,13 log CFU/g.

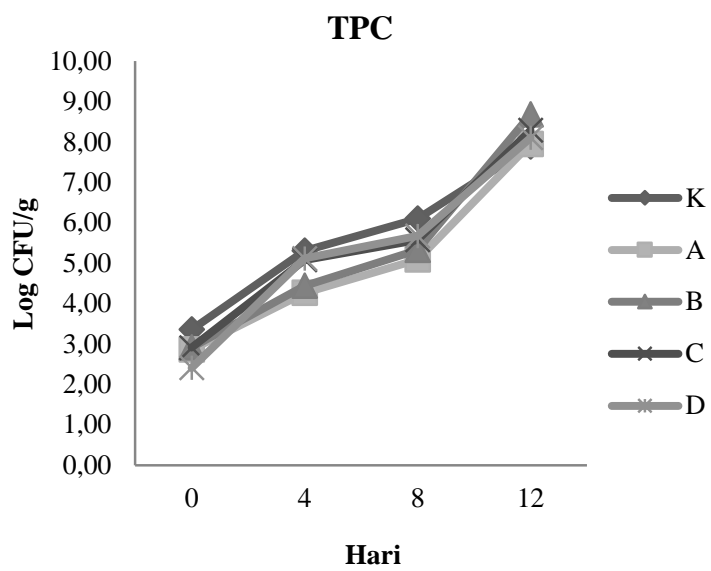

Gambar 1 Grafik Total Plate Count (TPC) Fillet Ikan Nila Merah dengan Perendaman Asam Asetat dan Penambahan Edible Coating Ekstrak Bawang Putih selama Penyimpanan pada Suhu $4 \pm 1^{\circ} \mathrm{C}$.

Pada hari ke-4 ini belum ada sampel yang melewati batas maksimum mikroba sebesar 5,5x10 $\mathrm{CFU} / \mathrm{g}$ atau 5,74 log CFU/g (Utami dkk, 2013). Pada hari ke-8, semua sampel mengalami peningkatan pertumbuhan mikroba. Sampel K sudah melewati batas maksimum penerimaan yaitu 6,10 log CFU/g lebih besar daripada 5,74 log CFU/g. Hal ini dikarenakan sampel kontrol tidak diberi perlakuan perendaman asam asetat dan penambahan ekstrak bawang putih pada edible coating yang dapat menghambat pertumbuhan mikroba. Sampel A dan B menunjukkan jumlah koloni mikroba yang lebih sedikit dibandingkan sampel $\mathrm{C}$ dan $\mathrm{D}$ walaupun sampel $\mathrm{C}$ dan $\mathrm{D}$ memiliki konsentrasi asam asetat lebih besar, hal ini mengindikasikan sangat kecil perbedaan pengaruh antara konsentrasi asam asetat $0,5 \%$ dan $1 \%$ dalam menghambat pertumbuhan mikroba. Pada hari ke-12, semua sampel mengalami peningkatan pertumbuhan mikroba dibandingkan hari ke-8 dan sudah tidak layak untuk dikonsumsi karena sudah melewati batas maksimum 5,74 log CFU/g. Hal ini disebabkan ekstrak bawang putih sebagai antimikroba lebih dari hari ke-10 telah berkurang daya hambatnya terhadap mikroba (Durairaj et al., 2009) serta konsentrasi asam asetat yang kecil sudah tidak mampu menghambat pertumbuhan mikroba. Pada pengujian TPC ini dapat disimpulkan bahwa perlakuan perendaman asam asetat dan penambahan ekstrak bawang putih pada berbagai kombinasi konsentrasi hanya dapat menghambat pertumbuhan mikroba pembusuk sampai hari ke-8.

\section{Derajat Keasaman (pH)}

Menurut Munandar dkk (2009) penurunan $\mathrm{pH}$ disebabkan menurunnya jumlah cadangan glikogen pada daging ikan. Menurut Nugraheni (2013) glikogen terus diubah menjadi glukosa melalui proses glikolisis melalui proses anaerob yang menghasilkan energi dan asam laktat sehingga daging lama-kelamaan akan lentur kembali dan $\mathrm{pH}$ menurun. Seperti yang dapat dilihat pada Gambar 2, pada hari ke-0, pH ikan masih dalam rentang 6,4-6,58 (dalam rentang ini sampel $\mathrm{K}, \mathrm{A}, \mathrm{B}$, dan $\mathrm{C}$ tidak berbeda nyata). Gabungan konsentrasi asam asetat dan bawang putih yang lebih besar dapat menurunkan $\mathrm{pH}$ secara signifikan yaitu pada sampel D yang memiliki konsentrasi asam asetat dan ekstrak bawang putih paling besar secara berturut-turut yaitu 1\% dan $30 \%$. Rendahnya $\mathrm{pH}$ sampel D disebabkan oleh besarnya konsentrasi asam asetat dan ekstrak bawang putih. Asam asetat dikenal sebagai pengawet dengan cara menurunkan $\mathrm{pH}$ bahan pangan (pengasaman). Sedangkan ekstrak bawang putih memiliki $\mathrm{pH}$ yang bersifat sedikit asam sekitar 5,9. Semua sampel mengalami penurunan yang signifikan dibandingkan pada hari ke-0. Pada hari ke-12, 
sampel K (kontrol) mengalami peningkatan $\mathrm{pH}$.

Menurut Nugraheni (2013) peningkatan $\mathrm{pH}$ merupakan titik awal indikator bahwa mikroba dapat beradaptasi dengan lingkungan. Mikroba pembusuk mengeluarkan enzim yang akan mencerna bahan pangan seperti protein menjadi ammonia dan senyawa volatil lainnya yang bersifat basa. Tidak adanya penambahan asam asetat dan ekstrak bawang putih merupakan penyebab kerusakan pada sampel $\mathrm{K}$ (kontrol) terjadi lebih awal daripada sampel lain.

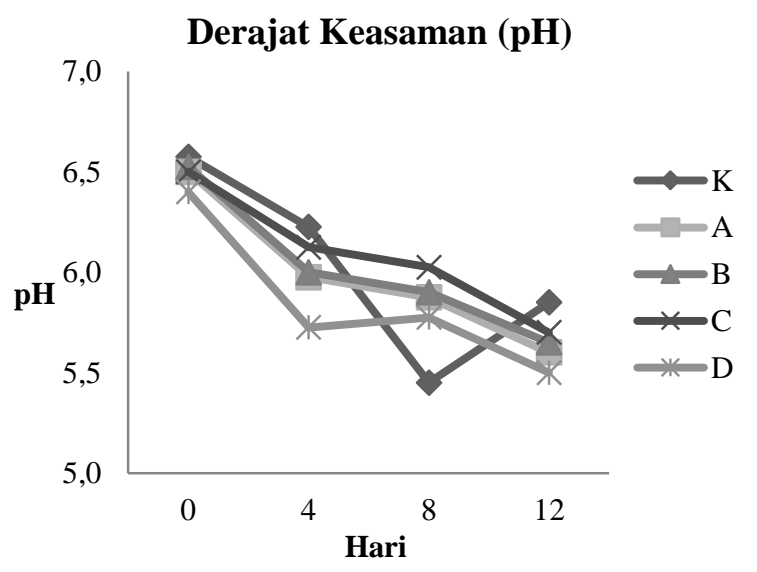

Gambar 2 Grafik Nilai Derajat Keasaman (pH) Fillet Ikan Nila Merah dengan Perendaman Asam Asetat dan Penambahan Edible Coating Ekstrak Bawang Putih selama Penyimpanan pada Suhu $4 \pm 1^{\circ} \mathrm{C}$.

\section{Kadar Air}

Secara keseluruhan, kadar air fillet ikan nila merah fluktuatif selama penyimpanan sampai hari ke-12, sekitar $77,7 \%$ sampai $81,2 \%$ (seperti yang diperlihatkan oleh Gambar 3). Hal ini menunjukkan bahwa perlakuan (larutan asam asetat dan edible coating ekstrak bawang putih), suhu pendinginan, kelembapan udara ruang pendingin, dan faktor lainnya tidak mempengaruhi kadar air selama penyimpanan. Sedangkan menurut Muchtadi (2011) rata-rata ikan air tawar memiliki kadar air daging $70-80 \%$. Tingginya kadar air pada daging ikan merupakan peluang untuk mikroba pembusuk tumbuh dan merusak daging sehingga tidak layak dikonsumsi.

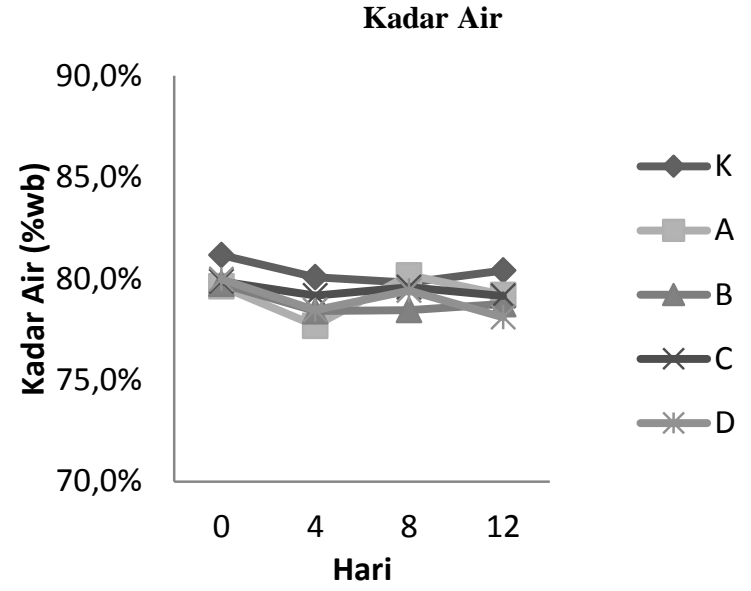

Gambar 3 Grafik Kadar Air Fillet Ikan Nila Merah dengan Perendaman Asam Asetat dan Penambahan Edible Coating Ekstrak Bawang Putih selama Penyimpanan pada Suhu $4 \pm 1^{\circ} \mathrm{C}$.

\section{Nilai Thiobarbituric Acid (TBA)}

Semua sampel mengalami kenaikan nilai TBA sampai hari ke-12 (seperti yang diperlihatkan oleh Gambar 4). Sampel K (Kontrol) memiliki nilai TBA yang paling rendah secara signifikan dibandingkan dengan sampel lain. Sampel K memiliki nilai TBA yang sangat rendah dibandingkan sampel A, B, C, dan D karena kekuatan gel dan konsistensi edible coating-nya lebih baik daripada perlakuan yang diberi ekstrak bawang putih. Hal ini menunjukkan bahwa semakin banyak kadar ekstrak bawang putih yang ditambahkan pada edible coating, maka semakin buruk kekuatan gelnya atau semakin renggang sehingga oksigen mudah berkontak dan bereaksi dengan lemak pada daging ikan. Menurut Sari dkk (2013) semakin besar kadar ekstrak bawang putih yang ditambahkan pada edible film, semakin kecil tensile strength/daya kuat tariknya. Penambahan ekstrak bawang putih mengurangi kekuatan ikatan antar amilosa sehingga kekuatan gelnya menurun. Hal ini menyebabkan pelapisannya kurang maksimal. Semua sampel masih dalam batas yang diperbolehkan yaitu di bawah $2 \mathrm{mg}$ malonaldehid/kg kecuali sampel B. Sampel B sudah tidak layak karena sudah sedikit melewati angka ketengikan yaitu sebesar $2,049 \mathrm{mg}$ malonaldehid $/ \mathrm{kg}$. Hal ini 
disebabkan gabungan perlakuan ekstrak bawang putih yang besar (30\%) mengakibatkan kekuatan gel edible coatingnya rendah, juga konsentrasi asam asetat yang lebih kecil $(0,5 \%)$ kurang dapat menghambat enzim mikroba yang merombak lemak.

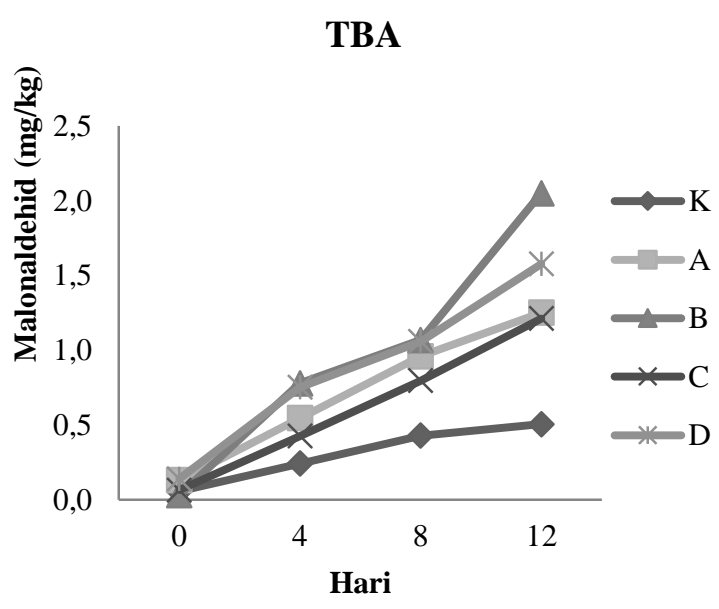

Gambar 4 Grafik Thiobarbituric Acid (TBA) Fillet Ikan Nila Merah dengan Perendaman Asam Asetat dan Penambahan Edible Coating Ekstrak Bawang Putih selama Penyimpanan pada Suhu $4 \pm 1^{\circ} \mathrm{C}$.

\section{Nilai Total Volatile Base (TVB)}

Menurut Nugraheni (2013) batas nilai TVB maksimum adalah $35 \mathrm{mg} \mathrm{N} / 100 \mathrm{~g}$. Pada penelitian ini, semua sampel mengalami peningkatan nilai TVB dibawah batas maksimum (dapat dilihat pada Gambar 5). Pada hari ke-12 sampel C memiliki nilai TVB paling rendah secara signifikan dibandingkan lainnya, sedangkan sampel A dan D tidak berbeda secara signifikan tetapi berbeda dengan sampel K dan B. Sampel K memiliki nilai TVB yang lebih tinggi secara signifikan, hal ini dikarenakan sampel kontrol tidak diberi perlakuan apapun sehingga enzim mikroba tidak terhambat dalam merombak protein menjadi senyawa volatil. Hal ini menunjukkan bahwa adanya perlakuan asam asetat dan ekstrak bawang putih mampu menghambat enzim yang dihasilkan mikroba dalam merombak protein yang menghasilkan senyawa amonia, trimetilamin, dan senyawa volatil.

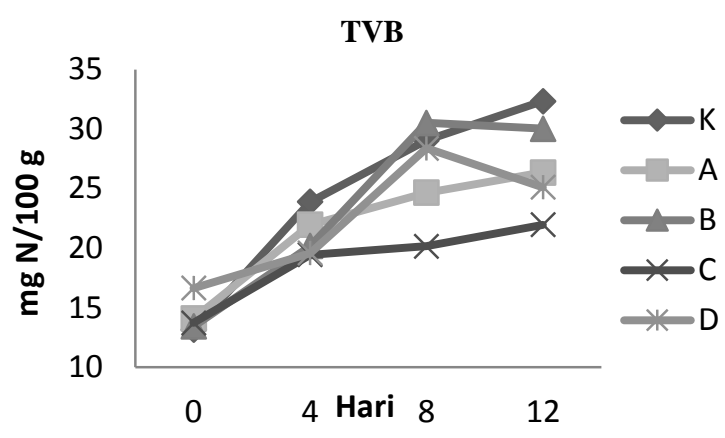

Gambar 5 Grafik Total Volatile Base (TVB) Fillet Ikan Nila Merah dengan Perendaman Asam Asetat dan Penambahan Edible Coating Ekstrak Bawang Putih selama Penyimpanan pada Suhu $4 \pm 1^{\circ} \mathrm{C}$.

\section{Warna}

Pengujian warna pada penelitian ini menggunakan alat Color Reader CR-400/410 Minolta. Sistem warna yang digunakan adalah Hunter's Lab Colorimetric System. Sistem notasi warna Hunter dicirikan dengan tiga nilai yaitu L (Lightness), a* (Redness), dan $\mathrm{b}^{*}$ (Yellowness). Nilai L, a, dan b mempunyai interval skala yang menunjukkan tingkat warna bahan yang diuji. Notasi L menyatakan parameter kecerahan (lightness) dengan kisaran nilai dari 0-100 menunjukkan dari gelap ke terang. Semakin tinggi nilai $\mathrm{L}$ maka sampel yang diuji menunjukkan kecenderungan warna lebih terang. Notasi a (redness) dengan kisaran nilai dari (-80)$(+100)$ menunjukkan dari hijau ke merah. Notasi b (yellowness) dengan kisaran nilai dari (-70) - (+70) menunjukkan dari biru ke kuning. Pada notasi L (Lightness) atau kecerahan dapat dilihat hari ke-0 sampai hari ke-12, pada hari ke-0 sampel yang diberi ekstrak bawang putih memiliki kecerahan yang lebih tinggi secara signifikan daripada sampel K (kontrol).

Tabel 5 Warna Fillet Ikan Nila Merah dengan Perendaman Asam Asetat dan Penambahan Edible Coating Ekstrak Bawang Putih selama Penyimpanan pada Suhu $4 \pm 1^{\circ} \mathrm{C}$ 


\begin{tabular}{|c|c|c|c|c|c|}
\hline \multirow{2}{*}{\multicolumn{2}{|c|}{ Perlakuan }} & \multicolumn{4}{|c|}{ Lama Penyimpanan (Hari) / Nilai Warna } \\
\hline & & 0 & 4 & 8 & 12 \\
\hline \multirow{5}{*}{$\mathrm{L}$} & $\mathrm{K}$ & $49,52 \pm 3,26_{a}^{\mathrm{A}}$ & $49,63 \pm 4,40^{\mathrm{A}}{ }_{a b}$ & $50,52 \pm 2,44_{a}^{\mathrm{A}}$ & $50,82 \pm 0,86^{\mathrm{A}}$ \\
\hline & A & $58,63 \pm 0,70_{c}^{A}$ & $55,16 \pm 4,21_{b}^{\mathrm{A}}$ & $57,16 \pm 1,44_{c}^{\mathrm{A}_{\mathrm{c}}}$ & $55,84 \pm 3,05^{\mathrm{A}_{\mathrm{b}}}$ \\
\hline & $\mathrm{B}$ & $53,54 \pm 0,69^{A}$ & $47,55 \pm 0,92^{\mathrm{B}}$ & $52,99 \pm 0,90^{\mathrm{A}}{ }_{\mathrm{ab}}$ & $52,78 \pm 0,26^{\mathrm{A}}{ }_{\mathrm{ab}}$ \\
\hline & $\mathrm{C}$ & $56,86 \pm 0,45^{\mathrm{A}}$ & $52,26 \pm 4,03^{\mathrm{B}} \mathrm{ab}$ & $54,98 \pm 2,28^{\mathrm{AB}}$ & $52,95 \pm 1,51^{\mathrm{AB}}$ \\
\hline & $\mathrm{D}$ & $61,80 \pm 0,08^{A_{d}}$ & $54,16 \pm 3,09^{B}{ }_{b}$ & $59,78 \pm 4,33^{A}{ }_{d}$ & $54,26 \pm 3,10^{\mathrm{B}}{ }_{\mathrm{b}}$ \\
\hline \multirow{5}{*}{$\mathrm{a}$} & $\mathrm{K}$ & $1,15 \pm 0,45^{\mathrm{A}_{c}}$ & $2,36 \pm 0,10^{\mathrm{B}}$ & $0,40 \pm 0,83_{c}^{A_{c}}$ & $2,18 \pm 0,59^{\mathrm{B}}$ \\
\hline & A & $-1,07 \pm 0,00_{b}{ }_{b}$ & $-0,84 \pm 0,27^{\mathrm{A}}$ & $-1,60 \pm 0,72^{\mathrm{A}}{ }_{\mathrm{ab}}$ & $-1,70 \pm 0,80_{a b}^{\mathrm{A}_{a b}}$ \\
\hline & $\mathrm{B}$ & $-1,18 \pm 0,44_{b}^{A}$ & $1,50 \pm 0,56^{\mathrm{B}}$ & $-0,51 \pm 0,08^{\mathrm{A}} \mathrm{bc}$ & $-0,75 \pm 0,61_{b}^{A_{b}}$ \\
\hline & $\mathrm{C}$ & $0,05 \pm 1,18^{\mathrm{A}} \mathrm{bc}$ & $-0,16 \pm 1,11_{a}^{\mathrm{A}}$ & $-0,81 \pm 0,55^{\mathrm{A}} \mathrm{b}$ & $-1,07 \pm 0,69^{\mathrm{A}}{ }_{\mathrm{ab}}$ \\
\hline & $\mathrm{D}$ & $-3,40 \pm 2,36_{a}^{\mathrm{A}}$ & $-1,13 \pm 0,48^{\mathrm{B}}{ }_{\mathrm{a}}$ & $-2,13 \pm 0,97^{\mathrm{AB}}$ & $-1,90 \pm 0,39^{\mathrm{AB}}$ \\
\hline \multirow{5}{*}{ b } & $\mathrm{K}$ & $-1,59 \pm 1,11^{\mathrm{A}}{ }_{\mathrm{a}}$ & $1,89 \pm 0,31^{\mathrm{C}_{a b}}$ & $-0,50 \pm 0,26_{a}^{\mathrm{B}}$ & $2,69 \pm 0,17^{C_{b}}$ \\
\hline & A & $1,50 \pm 0,85^{\mathrm{A}}{ }_{\mathrm{ab}}$ & $4,01 \pm 0,41^{C_{c}}$ & $2,39 \pm 0,71^{\mathrm{AB}_{\mathrm{b}}}$ & $3,20 \pm 0,65^{\mathrm{BC}}{ }_{b}$ \\
\hline & B & $-1,55 \pm 0,80^{\mathrm{A}}{ }_{a}$ & $2,96 \pm 0,17^{\mathrm{C}} \mathrm{bc}$ & $1,20 \pm 0,23^{\mathrm{B}}$ & $-0,45 \pm 1,34^{\mathrm{A}}{ }_{\mathrm{a}}$ \\
\hline & $\mathrm{C}$ & $4,08 \pm 4,37^{\mathrm{BC}}$ & $0,61 \pm 1,84^{\mathrm{AB}}{ }_{a}$ & $-0,81 \pm 0,55^{\mathrm{A}}$ & $4,69 \pm 0,96^{C_{b}}$ \\
\hline & $\mathrm{D}$ & $4,65 \pm 2,47^{A_{b}}$ & $2,03 \pm 0,83^{\mathrm{A}}{ }_{\mathrm{ab}}$ & $4,16 \pm 1,89^{A_{c}}$ & $3,32 \pm 2,39 \mathrm{~A}_{\mathrm{b}}$ \\
\hline
\end{tabular}

Keterangan: Nilai menunjukkan rata-rata \pm standar deviasi $(n=4)$. Notasi huruf kecil yang sama pada kolom yang sama tiap parameter uji dan notasi huruf besar yang sama pada baris yang sama menunjukkan tidak beda nyata pada taraf signifikansi $(\alpha=0,05)$. Perlakuan (Kadar asam asetat \& ekstrak bawang putih) : K (0\% \& 0\%), A $(0,5 \%$ \& 20\%), B $(0,5 \%$ \& $30 \%), \mathrm{C}(1 \%$ \& $20 \%)$, D (1\% \& 30\%).

Hal ini mengindikasikan ekstrak bawang putih menambah kecerahan daging karena ekstrak bawang putih terlihat mengkilap dan terang. Namun sampel dengan penambahan ekstrak bawang putih mengalami penurunan kecerahan warna yang lebih besar daripada sampel K. Menurut Sari dkk (2013) semakin besar kadar ekstrak bawang putih yang ditambahkan pada edible film, semakin kecil tensile strength/daya kuat tariknya. Penambahan ekstrak bawang putih mengurangi kekuatan ikatan antar amilosa sehingga kekuatan gelnya menurun. Hal ini menyebabkan pelapisannya kurang maksimal, sehingga oksigen dapat berkontak dengan senyawa pada daging ikan seperti hemoglobin menjadi methemoglobin yang mengubah warna darah tersisa dari cerah menjadi lebih gelap (Liviawaty dan Eddy, 2010). Pada notasi a (redness), semua sampel mengalami fluktuasi dari hari ke-0 sampai hari ke-12, sampel $\mathrm{K}$ pada hari ke-12 warna merahnya sedikit meningkat dibandingkan hari ke-0, sedangkan sampel A, B, C, dan D tidak berubah signifikan. Warna merah pada sampel $\mathrm{K}$ lebih tinggi secara signifikan daripada sampel yang diberi ekstrak bawang putih, hal ini mengindikasikan sebab-akibat yang sama dengan notasi L (lightness) yaitu edible coating pada sampel $\mathrm{K}$ lebih baik dalam pelapisan sehingga dapat mengurangi terjadinya oksidasi hemoglobin menjadi methemoglobin yang berwarna merah lebih gelap. Pada notasi b (yellowness), semua sampel mengalami fluktuasi dari hari ke-0 sampai hari ke-12, namun terlihat nilai notasi warna $b$ pada hari ke-0 dibandingkan hari ke12 tidak berbeda nyata. Warna kekuningan pada sampel fillet ikan nila merah diperkirakan karena daging ikan memiliki pigmen karotenoid, pigmen karotenoid bersifat larut lemak (Indrayati dkk, 2013).

\section{Penentuan Perlakuan Kombinasi Konsentrasi Asam Asetat dan Ekstrak Bawang Putih Terbaik}

Hasil penelitian menunjukkan adanya perbedaan pengaruh antar perlakuan $(\mathrm{K}, \mathrm{A}, \mathrm{B}$, $\mathrm{C}$, dan D) dalam menghambat kerusakan mikrobiologis dan fisikokimia fillet ikan nila merah selama penyimpanan. Parameter yang digunakan pada hari ke-8, karena pada hari ke-12 semua sampel sudah tidak layak menurut parameter TPC dengan jumlah 
mikroba yang telah melewati batas. Berdasarkan hasil tersebut dipilih salah satu perlakuan yang terbaik yaitu perlakuan $\mathrm{C}$.

\section{KESIMPULAN}

Perendaman fillet ikan nila merah dalam asam asetat dan pelapisan edible coating ekstrak bawang putih dapat menghambat kerusakan mikrobiologis dan fisikokimia sampai hari ke-8 pada suhu penyimpanan $4 \pm 1^{\circ} \mathrm{C}$. Perlakuan terbaik dalam mempertahankan kualitas fillet ikan nila merah adalah perlakuan $\mathrm{C}$ yaitu perendaman fillet dalam asam asetat berkadar $1 \%$ dan penambahan ekstrak bawang putih dalam edible coating dengan kadar $20 \%$.

\section{DAFTAR PUSTAKA}

Buckle, K.A., R.A. Edwards, G.H. Fleet, dan M. Wootton. 2010. Ilmu Pangan. Penerjemah Hadi Purnomo Adiono, Penerbit Universitas Indonesia. Jakarta.

Dewi, F. K. 2010. Aktivitas Antibakteri Ekstrak Etanol Buah Mengkudu (Morinda citrifolia, Linnaeus) terhadap Bakteri Pembusuk Daging Segar. Skripsi Jurusan Biologi, Fakultas MIPA, Universitas Sebelas Maret Surakarta.

Djarijah, A.S. 1995. Nila Merah : Pembenihan dan Pembesaran secara Intensif. Penerbit Kanisius. Yogyakarta.

Durairaj, S., Sangeetha S., and P. Laksmanaperumalsamy. 2009. In vitro Antibacterial Activity and Stability of Garlic Extract at Different $p H$ and Temperature. Electronic Journal of Biology, 2009, Vol. 5(1): 5-10

Indrayati, F., Rohula U., dan Edhi N. 2013. Pengaruh Penambahan Minyak Atsiri Kunyit Putih (Kaempferia Rotunda) pada Edible Coating terhadap Stabilitas Warna dan pH Fillet Ikan Patin yang Disimpan pada Suhu Beku. Jurnal Teknosains Pangan Vol 2 No 4 Oktober 2013 Hal 25-31.
Liviawaty, E. dan Eddy A. 2010. Penanganan Ikan Segar. Penerbit Widya Padjajaran. Bandung.

Muchtadi, T. R., Sugiyono, dan Fitriyono A. 2011. Ilmu Pengetahuan Bahan Pangan. Penerbit Alfabeta. Bandung.

Munandar, A., Nurjanah, dan Mala N. 2009. Kemunduran Mutu Ikan Nila (Oreochromis niloticus) pada Penyimpanan Suhu Rendah dengan Perlakuan Cara Kematian dan Penyiangan. Jurnal Teknologi Pengolahan Hasil Perikanan Indonesia Vol XII Nomor 2 Tahun 2009.

Nugraheni, M. 2013. Pengetahuan Bahan Pangan Hewan. Penerbit Graha Ilmu. Yogyakarta.

Sari, R. P., Septia T. W., Dyah H. W. 2013. Pengaruh Penambahan Ekstrak Bawang Putih (Allium sativum) terhadap Karakteristik Edible Film Pati Ganyong (Canna edulis Kerr.). Jurnal Teknologi Kimia dan Industri, vol. 2, no.3, tahun 2013, hal. 82-87.

Solopos, 2013. Produksi Ikan Nila di Kawasan Minapolitan Klaten Tembus 5.103 Ton. http://www.solopos.com/2013/10/28/pr oduksi-nila-di-kawasan-minapolitanklaten-tembus-5-103-ton-460117. Januari 2014]

Rusdy, A. 2009. Pengaruh Pemberian Ekstrak Bawang Putih terhadap Mortalitas Keong Mas. J. Floratek 5: $172-180$.

Utami. R., Kawiji, Edhi N., Muslika K., Dedy I. 2013. Pengaruh Minyak Atsiri Jahe Merah dan Lengkuas Merah pada Edible Coating terhadap Kualitas Fillet Ikan Patin. Agritech, Hal 399-406, Vol. 33, No. 4, November 2013. 